progressive corneal stromal melting because steroids can enhance the effect of the locally liberated collagenases which are probably responsible for this type of tissue loss. The intraocular pressure was regularly measured in all patients to detect any steroidinduced rise.

All patients were followed for at least four months two for over a year after stopping practolol, during which time all but one showed uniform improvement in symptoms and signs. The remaining patient (case 3 ) developed a progressive disorder suggestive of an atypical drug-induced S.L.E. syndrome and was treated with systemic steroids and azathioprine.

The conjunctival signs regressed with disappearance of the abnormal keratinization and reduction of the hyperaemia and vascular abnormalities leaving only a persistent subconjunctival fibrosis. Lacrimal gland function recovered enough for artificial tear drops to be used less often, though most patients still had reduced tear secretion.

Three to four months after stopping the drug the most striking feature was the normal appearance of the conjunctiva. It had become a mobile epithelium moving freely over a deeper subconjunctival fibrous sheet which made the fornices shallower but which was quite unlike the abnormal conjunctiva firmly bound to a dense fibrous mass which produces dense symblepharon in such conditions as mucous membrane pemphigoid. Though they remain at risk from secondary infection, reduced tear flow, and secondary changes in the lids, eyes that have shown adverse reactions to practolol can recover nearly normal function unless severely damaged at the time of the initial drug reaction.

\section{Discussion}

Two distinct adverse reactions to practolol have been described. Raftery and Denman (1973) described a S.L.E. syndrome, but nobody has noted any ocular abnormality in drug-induced S.L.E. syndromes. Felix et al. (1974) described a group of patients with various practolol-induced rashes, but in retrospect only three patients were found to have ocular symptoms or signs, and only five patients $(24 \%)$ had antinuclear antibody in the serum. The patients described here showed remarkably constant ocular signs and high titres of antinuclear antibodies and antibody binding to epithelial tissue. They showed no other signs of drug-induced S.L.E., however, and their syndrome seems to represent another clearly defined reaction to practolol.

The mechanism by which the tissue damage occurs remains unknown though two separate processes are probably responsible for the damage to the lacrimal gland and the conjunctiva. There is some evidence that the drug accumulates locally in lacrimal tissue and may have a local toxic effect on secretory cells. The conjunctiva, however, seems to be damaged by the antibody, which binds to intercellular components of the epithelium, and the vascular and fibrotic changes follow as a secondary effect. The relevance of these latter findings to other disorders in which conjunctival fibrosis and shrinkage occur has still to be shown, but this adverse drug reaction may provide valuable information about the processes which cause such damage in many types of ocular inflammation. The suggestions that practolol stimulates cyclic adenosine phosphate activity and impairs the functions of the T-lymphocyte population have not been confirmed or refuted, but further studies are in progress. It should be possible to show whether there is a genetically determined group involved and confirm the best method for assessing the early signs of the adverse reaction. Meanwhile, any patient receiving treatment with practolol who develops ocular irritation or discomfort should be examined for evidence of conjunctival abnormality and reduced tear flow.

I thank all my colleagues who referred cases and Dr. Graham Hughes, Hammersmith Hospital, for arranging the estimation of DNA-binding capacity.

\section{References}

Amos, H. E., Brigden, W. D., and McKerron, R. A. (1975). British Medical

Fournal, 1, 598.
Felix, R. H., Ive, F. A., and Dahl, M. G. C. (1974). British Medical fournal, 4,321 .

Hughes, G. R. (1971). Lancet, 2, 861.

Jones, B. R. (1961). Proceedings of the Royal Society of Medicine, 54, 109.

Raftery, E. B., and Denman, A. M. (1973). British Medical fournal, 2, 452.

Wright, P. (1971). Transactions of the Ophthalmological Society of the United Kingdom, 91, 119.

\title{
Untoward Effects Associated with Practolol: Demonstration of Antibody Binding to Epithelial Tissue
}

\author{
H. E. AMOS, W. D. BRIGDEN, R. A. MCKERRON
}

British Medical fournal, 1975, 1, 598-600

\section{Summary \\ An antibody which sticks to the intercellular region of xenogenic epidermal tissue has been shown by indirect immunofluorescence to be present in the serum of patients with practolol-induced eye damage. These antibodies and those found in patients with pemphigus were compared for their ability to bind to isolated epi- dermal cells. Binding was achieved only with the pem- phigus antibody, which suggests that it may have a different specificity from the antibody associated with practolol-induced eye damage.}

Department of Immunology, Institute of Dermatology, London E.9 H. E. AMOS, M.B., PH.D., Head of Department

W. D. BRIGDEN, M.B., M.R.C.P., M.R.C. Clinical Research Fellow R. A. MCKERRON, A.I.S.T., Senior Technician

\section{Introduction}

Practolol may be associated with an ill-defined rash (Wiseman, 1971; Felix et al., 1974), and lupus erythematosus cells and antinuclear antibodies are present in some patients taking practolol (Raftery and Denman, 1973). In most patients reported so far only vague reference has been made to possible eye damage, but Wright $(1974,1975)$ has described conjunctival signs which were associated with practolol consumption and sufficiently unique to constitute a new clinical entity.

We describe here an immunological investigation of sera from patients with adverse effects probably induced by practolol. Most patients had conjunctival damage, but some had rashes and signs of drug-induced lupus erythematosus.

\section{Patients and Methods}

Sera were obtained from three groups of patients. Group 1 consisted of patients who had taken practolol and were assessed as having specific conjunctival eye signs (Wright, 1975). These patients were 
not assessed dermatologically. Group 2 consisted mainly of patients who had some type of rash while taking practolol. There were also two patients with a possible lupus erythematosus syndrome thought to be induced by practolol. No clear information was available on the state of the patients' conjunctivae. Group 3 consisted of patients with mucous membrane pemphigoid and concomitant ocular damage. They had never taken practolol.

Serological Investigations.-The sera were tested by indirect immunofluorescence for antibodies against allogenic or xenogenic tissue. Standard immunofluorescence techniques were used with commercially available reagents (Wellcome Reagents Ltd.). The fluorescent staining was examined with a Reichert Zetopan microscope fitted with an HB200 mercury vapour lamp using a BG12/6 mm exciter filter and GG9/1 mm and $O G 1 / 1.5 \mathrm{~mm}$ absorption filters.

Preparation of Isolated Epidermal Cells.-Guinea-pig epidermal cells were prepared as an isolated suspension (Brigden and Amos, 1975). The cell suspension was filtered through gauze and washed in phosphate buffered saline. Immunofluorescence staining was carried out with cells still in suspension.

\section{Results}

The striking finding on indirect immunofluorescence was the deposition of immunoglobulin in the intercellular spaces of squamous epithelial tissue (fig. 1). The staining was confined to the intercellular regions and extended throughout the width of the epidermis. Fluorescent staining of the nuclei of the epidermal cells was also visible.

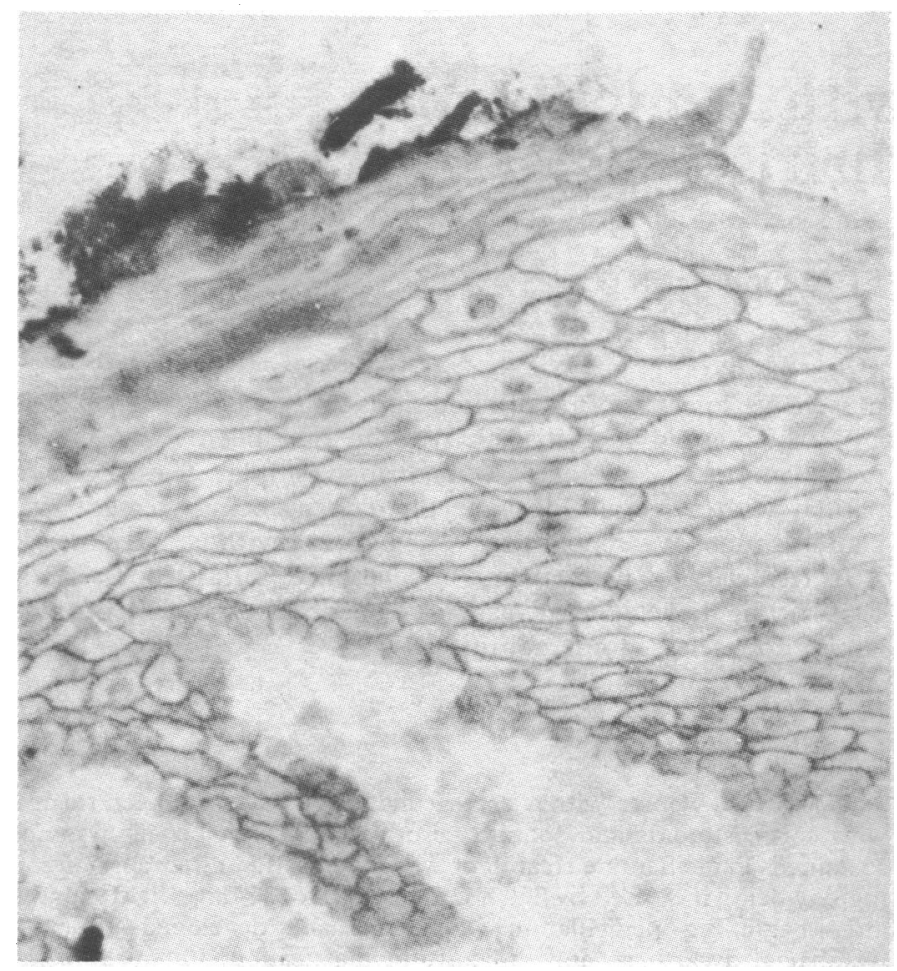

FIG. 1-Indirect immunofluorescent staining on guinea-pig lip using serum from group 1 at titre of $1 / 640$.

Twenty-nine sera from group 1 were tested for intercellular and antinuclear antibody, and 27 contained antibody reacting with the intercellular region of epidermis. The titres varied but eight patients had considerable staining at a serum dilution of more than $1 / 1280$ (see table). All the sera in this group had antinuclear antibody, but its titre did not seem to correlate with the level of intercellular antibody. The two serum specimens without intercellular antibody came from patients who were still taking practolol at the time of sampling, which may be significant. No convincing intercellular staining was shown in any of the sera from groups 2 and 3 . One specimen from group 2 , however, had some intercellular staining (at a titre of $1 / 80$ ) but it was confined to the basal layers. This patient was reported to have a rash but the conjunctivae were normal. Six of the 10 serum samples from patients with rashes showed antinuclear antibodies at titres of $1 / 10$, and the two samples from patients with a lupus erythematosus syndrome also showed these antibodies-at titres of $1 / 10$ and 1/1280. Two of the eight samples from group 3 showed antinuclear antibody at titres of $1 / 80$.

Antibody Titres* in 29 Sera from Patients in Group 1. Results are Numbers of Sera with Antibodies at Each Titre

\begin{tabular}{l|c|c|c|c|c|c}
\hline & $1 / 10$ & $1 / 80$ & $1 / 160$ & $1 / 320$ & $1 / 640$ & $1 / 1280$ \\
\hline Intercellular antibodies & 3 & 3 & 3 & 7 & 3 & 8 \\
Antinuclear antibodies & 7 & 18 & 2 & & 2 &
\end{tabular}

* Two sera gave no intercellular staining.

We examined conjunctival biopsy specimens from five patients in group 1. Three of the specimens had intact epidermis, and IgG immunoglobulin was shown by direct immunofluorescence in the intercellular region. Staining patterns in the remaining two specimens were difficult to interpret owing to the quality of the tissue.

As the intercellular staining in sera from group 1 was indistinguishable from that seen in pemphigus, and which is thought to be pathognomonic for pemphigus, we performed experiments to determine the relation between the practolol-induced antibody and the antibody found in pemphigus.

Determination of Antibody Class.-The use of fluoresceinlabelled antisera specific for the immunoglobulin heavy chains showed that antibodies from both pemphigus and practolol patients were IgG. We do not know if the antibody in practolol sera belongs to the same IgG subclass(es) as the pemphigus antibody. The antinuclear factor found in all the group 1 sera was of the IgM class. Antinuclear antibodies are not usually associated with pemphigus.

Comparison of Tissue and Organ Specificity.-The antibodies were tested for their ability to bind to the following substrates: guinea-pig and rat lip, oesophagus, conjunctivae, lacrimal gland, salivary gland, kidney, heart, stomach, adrenal, thyroid, bladder

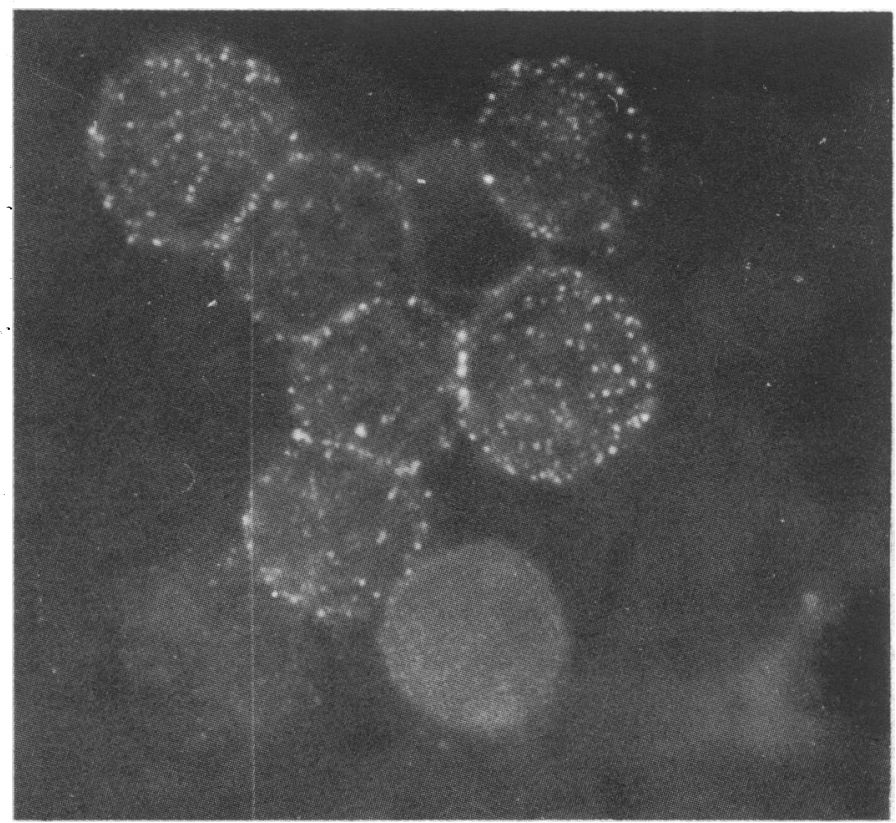

FIG. 2-Pemphigus antibody on epidermal cells in suspension. 
wall, and large gut. All the tissues which contained squamous epithelium stained readily with both pemphigus and practolol sera, but no significant staining was seen in any of the other tissues.

Ability of Antibodies to Stick to Isolated Epidermal Cells.The staining pattern obtained when trypsinized, aggregated epidermal cells were treated with pemphigus sera is shown in fig. 2. About one-third of the epidermal cells took up the antibody, which appeared localized in aggregates mainly around the periphery of the cells (Brigden et al., 1975). A similar cell preparation treated with 11 sera from group 1 did not stain.

\section{Discussion}

We have found an antibody which sticks to the intercellular region of squamous epithelial tissue and is associated with a distinct type of conjunctival damage induced by practolol, though it is too early to be dogmatic about the association. The fact that the intercellular region of the epidermis is the antibody's target in vitro inevitably raises the question of its relation to the antibody found in pemphigus even though the immunological specificity of both antibodies is unknown.

The pemphigus antibody will bind to trypsinized epidermal cells whereas the practolol antibody will not, which might suggest that the two antibodies bind to different determinants in the tissues. Unfortunately, there is no evidence to support the accepted concept that pemphigus antibodies react with skin antigens, and either antibody might behave as an IgG cytophilic antibody and attach itself to Fc receptors in target tissues. Under these circumstances it would be reasonable to argue that such an antibody might have specificity for antigens other than those of skin tissue, such as drug determinants.

The significance of the intercellular antibody in the sera of patients taking practolol is unknown, but a preliminary investigation in which serial serum samples from practolol-treated patients were tested for antibody suggests that the titre may reflect the degree of eye-associated tissue damage. If this is so then the antibody titre might be valuable in monitoring treatment or even predicting likely damage. We cannot, however, postulate any role for the antibody in the production of tissue damage until its specificity has been determined by further investigations.

We thank Mr. P. Wright, Dr. F. J. Zacharias, Dr. J. Cosh, Dr. P. Hickling, and Dr. L. Holt for supplying the sera.

\section{References}

Brigden, W. D., and Amos, H. E. (1975) Submitted for publication.

Felix, R. H., Ive, F. A., and Dahl, M. G. C. (1974). British Medical fournal, 4,321 .

Raftery, E. B., and Denman, A. M. (1973). British Medical fournal, 2, 452

Wiseman, R. A. (1971). Postgraduate Medical fournal, 47, Suppl. 2. p. 68. Wright, P. (1974). British Medical fournal, 2, 560 .

Wright, P. (1975). British Medical fournal, 1. 600.

\title{
Myasthenia Gravis associated with Penicillamine Treatment for Rheumatoid Arthritis
}

\author{
R. C. BUCKNALL, \\ A. ST. J. DIXON, \\ E. N. GLICK, \\ J. WOODLAND, \\ D. W. ZUTSHI
}

British Medical fournal, 1975, 1, 600-602

\begin{abstract}
Summary
Four patients with rheumatoid arthritis (R.A.) developed myasthenia gravis after taking penicillamine. In one patient withdrawal of the drug was followed by spontaneous remission of the myasthenia, and in two the dose of anticholinesterase was subsequently reduced. In the fourth patient continuing penicillamine treatment was associated with increasingly severe myasthenic features, but on withdrawal of the drug these resolved. As myasthenia gravis rarely complicates R.A. its onset in these patients shortly after the start of penicillamine treatment suggested that penicillamine may have precipitated this condition.
\end{abstract}

\section{Introduction}

At a recent international symposium Miehlke (1974), Bröll (1974), and Ott (1974) each reported that they had observed

Royal National Hospital for Rheumatic Diseases, Bath BA1 1RL

R. C. BUCKNALL, M.B., M.R.C.P., Medical Registrar

A. St. J. DIXON, M.D., F.R.C.P., Consultant Physician

Chase Farm Hospital, Enfield, Middlesex

E. N. GLICK, M.B., M.R.C.P., Consultant Rheumatologist

Department of Rheumatology, Prince of Wales's Hospital, London N. 15

J. WOODLAND, M.B., M.R.C.P., Senior Registrar

D. W. ZUTSHI, M.B., M.R.C.P., Consultant Physician muscle weakness and myasthenic signs in a total of four patients with rheumatoid arthritis (R.A.) who had been treated with penicillamine. Camus (1974) described similar features in a patient with systemic lupus erythematosus being treated with penicillamine. We report here four patients with active classical R.A. (American Rheumatism Association criteria (Ropes et al., 1959)) who developed myasthenia gravis after taking penicillamine for at least four months.

\section{Case 1}

A 49-year-old woman with a 12-year history of R.A. had been treated with corticosteroids and sodium aurothiomalate but benefit was not sustained. Penicillamine treatment was started, the initial dose of 250 $\mathrm{mg} /$ day being increased by $250 \mathrm{mg}$ each week to $1 \mathrm{~g} /$ day. Eight months after beginning penicillamine treatment she developed diplopia, dysphagia, dysarthria, and difficulty in mastication. Later she complained of generalized weakness, inability to sit up from the lying position unaided, and a drooping of her eyelids which became worse towards the evening. For about six months she had been unable to make tears but did not complain of a dry mouth. She was admitted to hospital where her disabilities were confirmed and proteinuria detected.

Investigations.-Haemoglobin was $10.0 \mathrm{~g} / \mathrm{dl}$; she was positive for rheumatoid factor (latex test); Rose-Waaler test showed a titre of 1/128; proteinuria was $1.3 \mathrm{~g} / 24 \mathrm{~h}$; thyroid function was normal; antinuclear factor was present but organ-specific antibodies were absent; chest radiography showed no evidence of a thymoma; and the Schirmer test showed no tear production. A therapeutic test with $10 \mathrm{mg}$ of edrophonium chloride intravenously gave an equivocal result, but $2 \mathrm{mg}$ of neostigmine intramuscularly produced a dramatic improvement in all her signs within five minutes which lasted for 30 minutes. She was then able to sit up unaided, ptosis was abolished, maintenance of upward gaze was improved from 30 seconds to two 